\title{
O Kazimierzu Narbucie Sch. P. nieco inaczej
}

\section{Kazimierz Narbutt w świadomości narodowej}

$\mathbf{K}$ azimierz Narbutt utrwalił się w świadomości Polaków przede wszystkim jako autor pierwszej, napisanej w języku narodowym logiki, jako twórca polskiej terminologii $z$ tej dziedziny. W krajach zachodnioeuropejskich, a szczególnie wśród niemieckich historyków nauki - wzbudził zainteresowanie jako popularyzator w Rzeczypospolitej Obojga Narodów systemu Christiana Wolffa - oczywiście głównie za pośrednictwem podręcznika logiki. Podręcznilk ten, wydany po raz pierwszy w $1769 \mathrm{r}{ }^{1}$, zostal przyjęty $\mathrm{z}$ aplauzem, gdyż posługując się językiem polskim, wprowadzał na grunt szkolny nowożytną myśl naukową. Niebawem - w 1775 r. - ukazała się druga, zmieniona edycja Logiki czyli rozwazania i rozsądzania rzeczy nauki ${ }^{2}$, a w ślad za nią wydania następne ${ }^{3}$. Jednocześnie - juz w okresie przedrozbiorowym - włączy 1 się Kazimierz Narbutt w nurt walki o tworzenie polskiej terminologii naukowej, by w narodzie tracącym swój byt państwowy, zachować własną tożsamość.

Wszystkie wymienione powyżej czynniki sprzyjały popularności tej niewielkiej objętościowo i eklektycznej - w osiemnastowiecznym rozumieniu tego słowa - książki szkolnej. Była ona bowiem wyrazem młodzieńczych fascynacji Narbutta najpierw filozofią „mistrza $z$ Halle”, nieco później Antonia Genovesiego - czołowego filozofa neapolitańskiego, autora dzieła Elementorum artis logico-criticae libri $V^{4}$. $Z$ najbardziej reprezentatywnym dorobkiem naukowym włoskiej elity intelektualnej zetknąl się polski pijar przebywając przez lat kilka we Włoszech, gdzie pogłębiał studia i gdzie otrzymał m. innymi od papieża Klemensa XIII „[...] indult na czytanie ksiąg zakazanych w przedmiotach religijnych, prawnych i historycznych..." 5 . Z filozofią Wolffa próbował zapoznawać się Narbutt jeszcze jako uczeń pijarslkiego kolegium w Szczuczynie Litewskim - na Ziemi Lidzkiej, gdzie wykładał filozofię i metafizykę Klemens Hołowiński admirator „mistrza $z$ Halle”, który posiadał w rękopisie polski przekład wyciągu $z$ filozoficznych dzieł Wolffa ${ }^{6}$. Faktycznie jednak dopiero w Wilnie, gdzie mlodociany pijar poglębial od 1759 r. studia w tamtejszym Collegium Nobilium, zetknął się bliżej $z$ systemem Christiana Wolffa. W tym czasie bowiem wrócila do Wilna $z$ Pragi grupa jezuitów, tj. Jan Bohomolec, Marcin Poczobutt, Tomasz Siekierski i Tomasz Zebrowski, którzy po odbyciu studiów pod kierunkiem zapalonego wolffianisty czeskiego - Josepha STEPLINGA - upowszechniali $z$ równym zapalem poglądy mistrza $z$ Halle na rodzimym gruncie ${ }^{7}$.

Tak więc studia Kazimierza Narbutta w Wilnie i we Włoszech wywarły niewątpliwy wplyw na merytoryczną zawar tość pierwszej polskiej logiki. Znalazły w niej odbicie poglądy co najmniej kilku przedstawicieli filozofii recentiorum, przede wszystkim jednak Christiana Wolffa oraz Antonie Genovesiego, nawiązującego do teorii Locke'a ${ }^{8}$. Zainteresowanie Logiką Kazimierza Narbutta nie 
zmniejszyło się w XX w. W 1958 r. ukazała się znakomita książka Olgierda Narbutta pt. O pierwszym polskim podręczniku logiki ${ }^{9}$, ukazująca źródła inspiracji intelektualnych 31-letniego autora i przeprowadzająca drobiazgową analizę porównawczą tekstu polskiego pijara głównie $z$ pierwowzorami Wolffa i Genovesiego. Wniosek płynący $z$ tej pracy nie mógł budzić wątpliwości: znaczne fragmenty książki Kazimierza Narbutta były wiernym przekładem na język polski zachodnioeuropejskich źródel, które zafascynowały go. Logika... miała więc charakter typowo eklektyczny, co jednak - chcę to podkreślić - bylo w „siecle des lumieres" zjawiskiem normalnym. Przypomnijmy chociażby w tym miejscu artykuł Denisa Diderota w Encyklopédie au Dictionaire raisonné des sciences, arts et metiers ${ }^{10}$. W dodatku tenże eklektyzm, znamionujący zawartość podręcznika logiki Narbutta, stał się niewątpliwie przyczyną zainteresowania nawet obecnie tą polską książką szkolną niemieckich uczonych, badających naukową spuściznę Christiana Wolffa oraz recepcję jego dzieł. W rezultacie na ich zamówienie napisałam rozprawę pt. War Kazimierz Narbutt ein Wolffianer? ${ }^{\text {111 }}$, opublikowaną w 2002 r. w międzynarodowym wydawnictwie.

I w tym miejscu zmieniam kierunek rozważań. Mimowolnie nasuwa się bowiem pytanie: jak należy rozumieć fakt, że Kazimierz Narbutt utrwalił się w ogólnej świadomości naukowej jako autor jednej w gruncie rzeczy książki, napisanej $\mathrm{w}$ wieku mlodzieńczym i stanowiącej jego naukowy debiut? $\mathrm{Czy}$ wyszły spod jego pióra inne rozprawy? Co stanowiło właściwą treść życia pijara, który wszak przeży 69 lat?

Poza Logiką... napisał on, wydaną w 1771 r., jeszcze jedną książkę „uczoną", a mianowicie $Z$ filozofii wybrane zdania, aczkolwiek ukazała się ona pod nazwiskiem jego ucznia $z$ wileńskiego pijarskiego Collegium Nobilium - Stefana Wereszczaka i Stanisława Godlewskiego. Zgodnie z przyjętym wówczas zwyczajem publikacja ta była utrwaleniem czcionką drukarską publicznej dysputy, jaką zorganizował nauczyciel - Kazimierz Narbutt $-z$ aktywnym udziałem swoich uczniów w Wilnie w $1771 \mathrm{r}$. Wspominany już imiennik pijara - Olgierd Narbutt - udowodnił, że autorem tej książki był nauczyciel, nie zaś jego wychowankowie wymienieni na karcie tytułowej ${ }^{12}$. Trzeba przyznać, że publikacja ta, chociaż obecnie prawie całkowicie zapomniana, jest znacznie bardziej dojrzała od Logiki... pod względem merytorycznym, stanowiąc jakby małą encyklopedię, składającą się z 96 tez filozoficznych i naukowych, m. in. nauk przyrodniczych, matematyczno-astronomicznych, fizycznych i innych; logice jest poświęcone zaledwie 8 tez, nawiązujących w niewielkim stopniu do poglądów Christiana Wolffa. Droga wiodąca od racjonalizmu „mistrza z Halle” poprzez logikę Genovesiego do teorii poznania Johna Locke'a, typowa zresztą dla przedstawicieli filozofii recentiorum w Rzeczypospolitej doby Oświecenia, byla jednocześnie zakończeniem twórczości naukowej Kazinierza Narbutta, finalizowanej publikacjami.

Dorobek pisarski młodego pijara uzupełnia przetłumaczona $z$ języka francuskiego na polski Nauka zolnierska króla pruskiego dla jego generałów dana - opublikowana w 1771 r. w Wilnie. Dodajmy, że we wstępie do tego dziela Fryderyk II został potraktowany jako wzór w sztuce wojennej. Książka ta podobnie jak dwie poprzednie - byla wyraźnie osadzona w ówczesnej polskiej rzeczywistości politycznej: wszak ukazala się podczas konfederacji barskiej. 
Dedykowana była jednak Michałowi Kazimierzowi Ogińskiemu - twórcy kanału jego imienia, zasłużonemu w rozwoju gospodarki kraju. Przypomnijmy, że Logikę.. dedykował Narbutt Pawłowi Brzostowskiemu - równie zaangażowanemu w działalności gospodarczej na Litwie, na polecenie którego zresztą młody pijar ten podręcznik napisał i na którego koszt wydał.

Zaginęły natomiast najprawdopodobniej dwa nie opublikowane rękopisy przekładów dzieł religijnych pióra Kazimierza Narbutta, tj. Evangîle méditée oraz La religion chrétienne méditée ${ }^{13}$. Bałamutne okazały się także informacje, ze Narbutt był autorem zamieszczonych anonimowo w „Monitorze” oraz „Zabawach Przyjemnych i Pożytecznych" wierszy ${ }^{14}$; wiersze w „Zabawach...” wyszły bowiem spod pióra jego bratanka - Wojciecha Narbutta.

Jak widać dorobek pisarski Kazimierza Narbutta, przypadający niemal wyłącznie na okres jego młodości, nie był zbyt wielki - PIORO nie stanowiło więc $z$ pewnością jego życiowej pasji. Na podstawie dwóch napisanych przezeń książek szkolnych - w tym wydanego co prawda po raz pierwszy w języku polskim, lecz eklektycznego podręcznika logiki - nie ma uzasadnienia, aby zaliczać Narbutta do grona filozofów, jak określono go np. w Nowym Korbucie ${ }^{\text {i5 }}$. Przypomnijmy, że doktorat otrzymał on w Akademii Krakowskiej nie z zakresu filozofii, lecz prawa.

Bieg zycia Kazimierza Narbutta w wieku dojrzałym, tj. 20 lat spędzonych w Warszawie, pozwala określić go jednoznacznie jako poważnego działacza edukacyjnego, zasłużonego członka Towarzystwa do Ksiąg Elementarnych, należącego niewątpliwie do intelektualnej elity czasów stanisławowskich. A ponadto nie należy zapominać, że Narbutt był księdzem - do 1775 r. pijarem, później sekularyzował się, zostając proboszczem w Radzyminie oraz w Lidzie. Portret byłego pijara bylby niepełny, gdyby nie uwzględniał jego dzialalności duszpastersko-organizacyjnej, która w świetle zapomnianych, niestety, materiałów źródłowych okazuje się nader interesująca.

\section{Salony i działalność edukacyjna}

Po kilkuletnim pobycie w Niemczech i we Francji, gdzie Narbutt przebywał z synami podskarbiego litewskiego - Michała Brzostowskiego jako ich guwerner, osiadl on w 1774 r. w Warszawie, zdradzając na lat 20 Wielkie Księstwo Litewskie, gdzie się urodził, kształcił, wstąpił do Zakonu Pijarów, gdzie przezywał swoje intelektualne fascynacje i zdobywał pedagogiczne doświadczenia. Teraz jego dotychczasowe życie miało zmienić się diametralnie.

Kazimierz Narbutt zamieszkał u kanclerza wielkiego litewskiego - Michała Fryderyka Czartoryskiego - wuja króla Stanisława Augusta Poniatowskiego, stając się jego zaufanym, bliskim współpracownikiem, co - siłą rzeczy - wprowadziło go na salony ówczesnej elity intelektualnej. Po śmierci kanclerza w sierpniu $1775 \mathrm{r}$. utrzymywał nadal przyjazne stosunki przez około lat $20 \mathrm{z}$ jego małżonką Eleonorą, której zresztą zawdzięczal probostwo w Radzyminie, gdzie księżna miała swą letnią rezydencję. Zasadniczym nurtem życia Kazimierza Narbutta podczas dwudziestoletniego pobytu w Warszawie stała się jednak dla niego niezwykle aktywna i rzetelna działalność w Towarzystwie do Ksiąg Ele- 
mentarnych. Był on czlonkiem ordynaryjnym tej instytucji - organu wykonawczego Komisji Edukacji Narodowej - od początku do końca jej istnienia, tj. w latach 1775-1792. Głównym zadlaniem tego gremium, w skład którego wchodzili wybitni przedstawiciele elity intelektualnej i pedagogicznej z Rzeczypospolitej Obojga Narodów, bylo przygotowywanie i opiniowanie nowych programów szkolnych oraz nowych podręczników dla szkół narodowych. Posiedzeniom Towarzystwa przewodniczyli członkowie Komisji Edukacji Narodowej, najczęściej najmłodszy spośród nich - Ignacy Potocki; sekretarzem był elssjezuita Grzegorz Piramowicz. Zebrania TdKE odbywały się raz w tygodniu, a w razie potrzeby i częściej (za wyjątkiem ferii). Członkowie ordynaryjni (zwyczajni), którzy otrzymywali stałą pensję, a do których - jak już wspominałam - należał Kazimierz Narbutt, mieli za każdą nieobecność potrącaną $z$ wynagrodzenia odpowiednią kwotę. Usprawiedliwieniem mogły być tylko złe warunki atmosferyczne, uniemożliwiające przybycie na posiedzenie, bądź choroba. I tak np. w Protokolach posiedzeń Towarzystwa do Ksiag Elementarnych ${ }^{16}$, pod clatami 24 i 31 stycznia 1783 r. czytamy, ze Kazimierz Narbutt był na sesji nieobecny „[...] dla niepodobieństwa przeprawy przez Wisłę...", oczywiście z powodu mrozu. A należał do najbardziej zdyscyplinowanych członków tego gremium, obciążonych w ciągu siedemnastu lat clziałania olbrzymią ilością różnorodnych zadań, wymagających nierzadko spotkań „ekstraordynaryjnych” - czasem nawet codziennych, np. z autorami podręczników, którzy byli zbyt opieszali, aby zdązyć wykonać podjęte zobowiązania we właściwym czasie. Tak więc Kazimierz Narbutt omawiał powstające teksty różnych książek szkolnych, poczynając od elementarza dla szkół paratialnych, poprzez gramatykę i naukę moralną, kończąc na matematyce. Sam $z$ kolei opracował Dykcjonarz geografii starożytnej, wymagający po głośnym czytaniu fragmentów wielu ulepszeń, czym jednak nie czuł się dotknięty.

Bardzo pracochłonne były też oceny nadsyłanych w ramach konkursu prospektów podręczników oraz przygotowywanie do wypisów szkolnych tłumaczeń tekstów autorów starożytnych. Dodatkowym obciążeniem było dokonywanie corocznego ,sumariusza” czyli podsumowania wszystkich prac wykonanych w tym okresie przez Towarzystwo do Ksiąg Elementarnych.

Narbutt uczestniczył tez w przygotowywaniu Ustaw szkolnych, co było bardzo poważnym przedsięwzięciem edukacyjnym, wymagającym wiedzy i doświadczenia pedagogicznego. Sjełniał przy tym jednocześnie polecenia doraźne, jak np. konsultacje $z$ Joachimem Chreptowiczem w sprawie miar i wag w Wielkim Księstwie Litewskim, aby w przygotowanych nowych podręcznikach arytmetyki i geometrii korespondowały one $z$ miarami "koronnymi" i zagranicznymi. Tych zadań i poleceń zarówno o znaczeniu podstawowym jak i barclzo drobiazgowych było mnóstwo, a wypełniał je nader skrupulatnie duchowny obracający się w najwyższych kręgach ówczesnej oświeconej elity magnackiej, mający kontakty $z$ dworem królewskim.

O zaangażowaniu Narbutta w pracach Towarzystwa do Ksiąg Elementarnych świadczą liczne teksty zachowane w rękopisach, np. o prospekcie podręcznika matematyki L'Huilliera ${ }^{17}$ czy o prospekcie podręcznika logiki. Odnotujmy przy tym interesujący fakt. Aczkolwiek Kazimierz Narbutt był w Towarzystwie do Ksiąg Elementarnych osobą liczącą się, cieszącą wysokim uzna- 
niem, nie traktowano go na prawach wyjątkowych. Jego logika - wszak pierwsza w języku polskim - weszla do obiegu szkolnego tylko w Wielkim Księstwie Litewskim - w dodatku uznana przez Komisję Edukacji Narodowej jedynie jako podręcznik tymczasowy. Narbutt natomiast - wypełniając polecenia TdKE, opracował uwagi do przysłanego w ramach konkursu prospektu podręcznika logiki pod dewizą: Ratiocinatio sine veritate aut veritas sine ratiocinatione. $\mathrm{C} z y \dot{z}$ w kontelsście tych przykładów, świadczących o wieloletnim, bezinteresownym zaangażowaniu Narbutta w sprawy edukacyjne w okresie jego 20-letniego pobytu w Warszawie - nie należy odejść od stereotypu widzenia w nim głównie autora pierwszej napisanej w języku polskim logiki?; w dodatku logiki eklektycznej i budzącej zastrzeżenia zarówno Komisji Edukacji Narodowej jak i samego twórcy, który przebywając wśród elity intelektualnej czasów stanisławowskich oceniał z nieco innej perspektywy swoje młodzieńcze naukowe fascynacje.

\section{Biale plamy}

Chciałabym, ażeby ten artykuł wyeliminował białe plamy z życiorysu Kazimierza Narbutta. Czy jednak faktycznie wyeliminuje? Żywotność błędów i niedomówień w pracach naukowych - wbrew istniejącym materiałom źródłowym jest wręcz zdumiewająca!

Pierwsza „biała plana” - dotąd nie wypełniona - to miejsce urodzin Kazimierza (faktycznie Daniela, gdyz Kazimierz - to imię zakonne) Narbutta. Wszystkie dotychczasowe opracowania i encyklopedie podają, że urodzil się on w Dokudowie lub Krupie - na Ziemi Lidzkiej ${ }^{19}$. Tymczasem w kościele parafialnym Świętego Krzyża w Lidzie (znajdującym się przy ul. Suwalskiej), w dobrze zachowanych starych księgach znajdowała się jeszcze w okresie międzywojennym (dziś już nieistniejąca) metryka chrztu Narbutta. Dotarł do niej w $1938 \mathrm{r}$. dzięki życzliwości ówczesnego dziekana - księdza Hipolita Bojaruńca - p. Aleksander Śnieżko, autor wielu artykułów w regionalnym czasopiśmie „Ziemia Lidzka”. Oto jego informacja na ten temat: „[...] Czytany wypłowiałe drobne pismo łacińskie pisane gęsim piórem, że dnia 5 stycznia 1738 r. ks. Piotr Strokowski, proboszcz lidzki, ochrzcił nienowlę imieniem Daniel Kazimierz. Urodzone $z$ szlachetnej rodziny Kazimierza Narbutta, miecznilka lit. z Krupy i Marianny $z$ domu Nowickiej, ślubnych małżonkow. Rodzicami chrzestnymi byli: Michał Narbutt z Perepeczyc i Antonina Jurewiczowa. W drugiej parze: Zygmunt Jurewicz i Aleksandra Nowicka, podczaszyna sandomierska..." ${ }^{120}$. Krupę, znajdującą się w odległości $8 \mathrm{~km}$ od Lidy wymieniał także jako miejsce narodzin Daniela - Kazimierza Narbutta jego stryjeczny wnuk - Teodor Narbutt, znany historyk i historiograf Wielkiego Księstwa Litewskiego, autor dziewięciotomowego dzieła: Dzieje starożytne narodu litewskiego.

Czyż przytoczone powyżej materiały nie rozstrzygają ostatecznie, że miejscem urodzenia autora Logiki... była Krupa?

„Białą plamą" w biografii Kazimierza Narbutta jest jego działalność jako proboszcza lidzkiego w latach 1783-1786. Jednak - jak się okazało - i tę lukę wypełnił opublikowany juz w okresie międzywojennym, a nieznany dotąd dokument, tj. instrukcja, którą w 1785 r. napisał sam Kazimierz Narbutt. Oryginał tego 
nader interesującego pisma, ukazującego, jak można być jednocześnie proboszczem w dwu odległych od siebie o kilkaset kilometrów kościołach, znajdował się w prywatnym posiadaniu p. Michała Szymilewicza, który opublikował je in ex-tenso w 200-lecie urodzin Kazimierza Narbutta, w przywoływanej już "Ziemi Lidzkiej”21. Niestety, nikt z piszących o Narbucie tego dokumentu nie wykorzystal.

Cofnijmy się jednak do początków jego duszpasterskiej działalności. Ażeby objąć obowiązki proboszcza, musiał Kazimierz Narbutt, należący wszak do zakonu OO. Pijarów, sekularyzować się. Otrzymał dyspensę około 1775 r. wszakże - jak informuje Antoni Moszyński Sch.P. - z zastrzeżeniem „zachowania znaku, że jest pijarem". Już jako kapłan świecki mógł otrzymać od Eleonory Czartoryskiej - księżnej wdowy po Michale Czartoryskim - prezentę na probostwo w Radzyminie, gdzie księżna miała swą letnią rezydencję i gdzie zastąpił dotychczasowego proboszcza - Ignacego Ostoję Nagurczewskiego. Zasługi księdza Narbutta dla Radzymina były znaczne, tj. wybudowanie w ciągu „7 kwartałów nowego murowanego kościoła, [...] który książę Michał Poniatowski, wówczas biskup płocki, później prymas, w przytomności króla Stanisława Augusta konsekrował, a król odlane dzwony pod swem imieniem poświęcone do rzeczonego kościoła ofiarował; tu Narbutt w dni niedzielne i świąteczne przybywał z Warszawy i jak dobry pasterz sam zwykle wielkie nabożeństwa odprawiał, miewał nauki, słuchał spowiedzi i inne posługi parafialne spełniał. Wspomniany KRÓL poważał wielce i względami swemi zaszczycal Narbutla, ozdobił go orderem św. Stanisława przy reskrypcie 23 listopada 1793; i nadto, w czasie czteroletniego Sejmu, kiedy za zezwoleniem dworu rzymskiego nowy miał nastapić poclzial diecezji w Polsce i Litwie, przyrzekł mianować go pierwszym biskupem projektowanej diecezji grodzieńskiej, która na miejsce inflanckiej miała być erygowana..."22. Oczywiście na zainteresowanie Stanislawa Augusta Poniatowskiego wyposażeniem kościoła w Radzyminie oraz osobą jego proboszcza wywarła niewątpliwy wpływ blisko spokrewniona z królem kanclerzyna Czartoryska, zaangażowana emocjonalnie i finansowo w jak najrychlejsze oddanie do uzytku wiernych nowego kościoła radzyminskiego. W „Gazecie Warszawskiej” z lat 1779-1782 aż roi się od opisów poszczególnych etapów budowy tej świątyni, uroczystości religijnych i towarzyskich, a także informacji o przyjeździe do Radzymina króla, odwiedzającego Eleonorę Czartoryską oraz biskupów Michała Poniatowskiego czy Adama Naruszewicza ${ }^{23}$. Właśnie na podstawie tych osiemnastowiecznych prasowych lekstów został odtworzony dość wiernie w rozprawie Kościól radzymiński. Uroczystości poświęcenia. Proboszcze, napisanej w połowie XIX stulecia (a prawie nieznanej) ${ }^{24}$ obraz działalności Kazimierza Narbutta jako proboszcza radzymińskiego. W kontekście tak wielkiego zaangażowania w duszpastersko-organizacyjne działania w podwarszawskim Radzyminie trudno wyobrazić sobie, aby mógl on jednocześnie spełniać powinności proboszcza kościoła w Lidzie i - szczerze mówiąc-pomijano ten temat milczeniem. A jednak - jak dowodzi wspomniany już, opublikowany przez Michała Szymielewicza w "Ziemi Lidzkiej” rękopis Kazimierza Narbutta, sprawowanie funkcji proboszcza lidzkiego - co prawda zaocznie - nie było mu obojętne. Tekst tego osiemnastowiecznego dokumentu jest tak interesujący i rzuca tak nowe światło na postać księdza Narbutta, że 
warto by było zaprezentować go in extenso, co zapewne uczynię w przyszłości, usuwając tym samym ostatecznie i tę „białą plamę" z jego życiorysu. Teraz ograniczę się do krótkiego streszczenia, przytaczając w oryginale zaledwie pierwsze $z d a n i a$ jednej $z$ obszernych, instrukcji lidzkiego proboszcza $z$ dnia 10 lipca $1783 \mathrm{r}$.

„[...] Niżej podpisany daję tę moją instrukcję p. Pawlowi Bagińskiemu ustanowionemu zawiadowcy plebanii lidzkiej, co do jej wszelkich dochodów. I. P. Paweł Bagiński we wszystkim ma się dokładać w J. p. Narbutta, wojskiego lidzkiego i za kwitami jemu pieniężne dochody oddawać..."25.

Wspominany wielokrotnie w dokumencie wojski lidzki - Wojciech Narbutt - był bratem księdza Kazimierza Narbutta i jemu podlegał administrujący dobrami probostwa Paweł Bagiński, mający pieczę nad prawidłowym, regularnym dopływem dochodów $z$ należących do probostwa wsi, a nawet szynków, $z$ którymi należy rozliczać się w każdą sobotę. Obowiązki duszpasterskie spełniali w zastępstwie nieobecnego w Lidzie proboszcza zatrudniani przez Narbutta księża świeccy lub zakonni - przeważnie karmelici.

„[...] Dla księdza trzymać parę koni, powóz, człeka, chłopca i kucharza lub gospodynię starą...” lecz jednocześnie „[...] dochody liościelne co miesiąc odbierać i księdza rejestra podpisywać, a oddawszy w. j. p. wojskiemu Narbuttowi, kwity od niego odbierać..."26 - czytamy w tym zaskakującym pragmatyzmem i drobiazgowością ,starym dokumencie”.

„Białą plamą" (chociaż usiłuję ją powoli zapełniać) pozostaje natomiast działalność księdza Narbutta jako opata paradyskiego. Czyżby poprzestawał tylko na chętnym używaniu tego tytułu? Mimo zamysłu i starań króla Stanisława Augusta Poniatowskiego nie został on biskupem grodzieńskim, przeszkodziły temu dramatyczne losy Rzeczypospolitej. Tak się jednak układały dziwnie losy Kazimierza Narbutta, że zarówno dzieciństwo i lata młodzieńcze, jaki schylek życia spędzil on na macierzystej Ziemi Lidzkiej, na którą powrócil po trzecim rozbiorze Polski. Osiadl w Radziwoniszkach - majątku brata, w poblizu Lidy. Podkreślając swą więź z Zakonem Pijarów, poświęcil kamień węgielny pod kościół pijarski w Lidzie. I była to chyba jego ostatnia posługa duszpasterska.

Przed paroma laty odwiedzilam znajdujące się dziś na Białej Rusi Radziwoniszki. Grobu Kazimierza Narbutta, niestety, nie odnalazłam, gdyż kościół, w którego krypcie był pochowany, juz nie istnieje, zastąpiony przez niewielką cerkiewkę. Mieszkańcy Radziwoniszek i okolic nie wiedzą już nic o rodzinie Narbuttów.

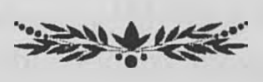

\section{Przypisy:}

${ }^{1}$ K. Narbutt, Logika czyli rozważania i rozsądzania rzeczy nauka, Wilno 1769.

${ }^{2}$ Podróże zagraniczne i kontalkty $z$ uczonymi zachodnioeuropejskimi zdystansowały nieco stosunek Kazimierza Narbutta do poglądów Christiana Wolffa, usiłował on je lączyć z elementami teorii neapolitańczyka Antonia Genovesiego i innych przedstawicieli 
filozotï recentiorum, budzących zainteresowanie w siecle des Lumieres. Druga edycja ukazała się również w Wilnie.

${ }^{3}$ Wilno $1782,1791,1799$.

${ }^{4}$ Antonio Genovesi (1713-1769) był profesorem filozofii Królewskiej Akademii w Neapolu. Dzieło jego - być może z inicjatywy Narbutta - zostało wydane w Polsce (Warszawa 1771 ).

${ }^{5}$ A. Moszczeński, Wiadomość o Kazimierzu Narbucie, autorze logiki polskiej, „Roczniki Towarzystwa Naukowego Krakowskiego", t. 2, Kraków 1843, s. 253.

${ }^{6}$ Johann Daniel Janozki (Jaenisch, Janocki), Lexicon derer itztlebenden Gelehrten in Polen, Wrocław 1775, t. 2, s. 141.

${ }^{7}$ S. Bednarski SJ, Upadek i odrodzenie szkół jezuickich w Polsce, Kraków 1933, s. 313 .

${ }^{8}$ Na temat Genovesiego zob. m.in. M. Affek, Związki polsko-włoskie w naukach prawnych, Warszawa 1995, passim.

${ }^{9}$ Ksiązkka wydana w Łodzi.

${ }^{10}$ Wyd. Paris 1755, t. 5, s. 270.

${ }^{11}$ I. Stasiewicz-Jasiukowa, War Kazimierz Narbutt ein Wolffianer?, w: Europa in den trïhen Neuzeit, Band 6: Mittel-, Nord- und Osteuropa, Böhlau Verlag Köln-WeimarWien 2002, s. 315-324.

${ }^{12}$ O. Narbutt, op. cit., s. 99.

${ }^{13}$ Źródłem tej informacji jest praca A. Moszczeńskiego, zob. przypis 5.

${ }^{14}$ K. Estreicher, XXIII, s. 39. Informację tę koryguje Nowy Korbut, t. V, s. 370.

${ }^{15}$ Nowy Korbut, t. V, s. 369; w: Bibliografii filozofii polskiej 1750-1830 (Warszawa 1955, s. 94), K. Narbutt został określony jako „pijar, profesor filozofii w kolegium w Wilnie".

${ }^{16}$ Protokoły posiedzeń Towarzystwa do Ksiąg Elementarnych, (wyd.), T. Wierzbowski, Warszawa 1908, s. 63.

${ }^{17}$ Zespół rkps. Uwagi Towarzystwa waględem ułożenia programma na książki elementarne... (Arch. Główne Akt Dawnych), zostal zniszczony w 1944 r.

${ }^{18}$ Ibidem.

${ }^{19}$ Zob. A. Moszyński, Sch.P. op. cit., (przypis 5), s. 251; [anonim] Kościół radzymiński. Uroczystości poświęcenia. Proboszcze, „Pamiętnik Religijno-Moralny”, t. XVIII: 1850, s. 507; O. Narbutt, O pierwszym polskim podreczniku logiki, Łódź 1958; J. Buba, Sch.P. w: Diccionario Enciclopedico Escolapio, Salamanca 1983, vol. 2 s. 396; PSB 22/3 z. 93; Nowy Korbut, V, s. 369; Catalogus Clericorum Regularium Pauperum Matris Dei Scholarum Piarum in Lithuania Provincia ab erectione eiusdem Anno Domini 1736 conscriptus, (Arch. OO. Pijarów w Krakowie), k. 18 odnotowuje tylko: Casimirus a s. Chrysostomo Daniel Narbutt Lithuanus ex Palatinatu Viln. Dioec. eiusdem, ur. 3 I 1738...

${ }^{20}$ "Ziemia Lidzka”, 1938, nr 12, s. 150-151.

${ }^{21}$ Ibidem, s. 151-153.

${ }^{22}$ A. Moszyński, op. cit., s. 255.

${ }^{23} \mathrm{~Np}$. „Gazeta Warszawska”, 1779, nr 43 i 75 (suplement); 1781, nr 44 (suplement) i nr 49 i 50, nr 77 (suplement); 1782, nr 73.

${ }^{24}$ Zob. przypis 19.

${ }^{25}$ M. Szymielewicz, Stary dokument, „Ziemia Lidzka”, 1938, mr 12, s. 151.

${ }^{26}$ Ibidem, s. 152. 